AMERICAN JOURNAL OF SOCIAL AND MANAGEMENT SCIENCES

ISSN Print: 2156-1540, ISSN Online: 2151-1559, doi:10.5251/ajsms.2011.2.1.56.75

(C) 2011, ScienceHuß, http://www.scihub.org/AJSMS

\title{
Building construction project management success as a critical issue in real estate development and investment
}

\author{
${ }^{1}$ Dr. Chinedu Chidinma Nwachukwu and ${ }^{2}$ Fidelis I. Emoh
}

\author{
${ }^{1}$ B.Sc (Est Mgt), M.Sc (Project Mgt), Ph.D (Project Mgt), PMP, ANIVS, FCRMI, Lecturer, \\ Department of Project Management Technology, Federal University of Technology, Owerri, \\ Imo State. GSM; 08033289740, E-Mail nedumchisma@yahoo.com \\ ${ }^{2}$ B.Sc., M.Sc. (Est Mgt), MBA (Banking \& Finance), FNIVS, RSV, MNIM. Head, Department \\ Of Estate Management, Nnamdi Azikiwe University, Awka Tel: 08033532597. \\ Email: iecon2003@yahoo.com.
}

\begin{abstract}
The strategic importance of building as an economic facility, the construction or developmental process and its investment potential are some attributes that attract all sectors of the economy to its projecting rays. Building facility is like a catalyst that not only serve as an engine that energies every other sector of the economy but gives impetus to the developmental rating of the environment. We know that all business activities for both public and private sector are housed in a structure called building, production activities, medical and health care, agro based activities, educational activities, political activities, sports, transport sector to mention a few cannot operate proficiently without having direct or indirect need for housing facility. The production of building facility as we refer it to building construction or developmental process attracts professionals from all fields of life and non professionals. Not only that, housing development employment cut across all categories of human endeavor. Building material production, marketing, distribution, supply, storage has a long and strong chain like impact on the economy as we know in commerce that production is not complete unless the products get to the hands of the final consumers. The income generated by way of receiving wages and salary, buying and selling by people within and outside the country contributes positively to the world economic growth. The investment attraction of building development by public and private sectors of the economy anchor on its indispensable and strategic importance as a solid rock of support and strength to all sectors of the economy. To the estate surveyor and Valuer, more than eighty percent of our professional activities revolves around building facility. To this end, any effort to encourage investment in building facility should be seen as a step in the right direction. One of the steps which form the main focal point of this paper is making sure that building developments are project managed to achieve success thereby reducing the rate at which building construction projects fail, suffer abandonment and reduce if not eliminating the rate at which buildings collapse in Nigeria.
\end{abstract}

Keywords: Construction, management, real estate, investment

\section{INTRODUCTION}

Achieving success in building implementation process is the major function of project management. According to Nwachukwu, et al (2010) the rate at which building construction projects fail, or are abandoned, and the collapse of buildings, some even under construction, is retrogressive in a developing economy like Nigeria. When there is a problem of building development failure, abandonment or collapse, everybody looks up to the engineers who in their professional pride and personality ego accept the blame but could not un-ravage the menace. The answer to project success, failure, abandonment, and collapse of building construction lies in efficient project management. Building construction projects must be made to succeed because its execution often involve substantial funds, the loss through failure or abandonment, has a crippling effect on the capabilities of the investors, the financiers and for the fact that scarce resources are tied down for a long time as opportunity cost for its alternative uses. The project may also be the only future hope of the client; therefore he may expect nothing but success. Efficient project management is very important 
especially in the building construction industry which rank very high among other economic sectors in terms of inter-sector linkages. The importance of this sector as an agent of development is enhanced by its ability to provide gainful employment for the world's teeming population. According to Roy, (2005) "it is evidenced that noticeable development and the aesthetic transformation of the environment is bound up with and predicated on the building construction industry". Building construction industry is a major factor in the social and political integration of the society and ranks as one of the major budgetary areas of developing economies (Nwachukwu, 2008). The building construction industry is proven to be the corner stone and bedrock of rapid economic growth of any nation (Bhavesh, 2006). The products of construction industry are desired mainly for the services which they help to create as most business, social, religious, economic, industrial activities etc operate on building infrastructure (Nwachukwu, 2008). According to Eric, (2003), "the industry is likely to remain a major area of development activity as the need for the provision and replacement of infrastructure become more important in the years ahead". As we have seen that building development sector of the construction industry is a catalyst, a rock, and the strongest base for rapid economic growth, it therefore becomes very imperative that building projects are project managed efficiently to succeed. The success of a building project is very important in a developing economy if we critically analyze the quantum of resources wasted and its negative impact to the Gross Domestic Product(GDP) of the a nations economy. For the fact that building development process employs both professionals and non-professionals from all the fields of life, is an indication that this sector has a geometric progression financial impact on the economy. This means that success will reflect the sector as an engine of growth but failure, abandonment and collapse a catastrophe to nation building economically.

The problem: The performance of any building development project (be it public or private) depends on the strategy for success adopted by the organization responsible for its implementation and execution. The strategies for success in any building project are implemented in the management of the Project Time, Cost, Quality and Material management using project life cycle concept. In most cases, both public and private building construction projects are hardly completed on time, within cost, quality and material specifications. New buildings and newly rehabilitated or maintained infrastructure become decrepit and wrecked within a few months of commissioning despite the capital commitments on them. Collapse of building facilities some even during construction in Nigeria can best be described as a holistic financial lost like a prudent investor dramatically digging a hole and burying his life savings and staving alternative investment opportunities. Building construction failure, abandonment and collapse dose not encourage development and investment and that calls for project management solution.

Project management is believed to be justified as a means of avoiding the ills inherent in the construction and production sectors of the economy and for which reasons most projects fail and or abandoned. The project managers role arises from the need for a technical expert to take charge, control of events on the project implementation process, someone who understands the intricacies of co-ordinating, controlling, organizing and directing the efforts and activities of the professional team and the physical problems of implementation process with the needs in the decision making process. The success of any project implementation process in the construction industry in the public and private sectors depend largely on the project manager's concept on staff appointments and control, strict monitoring of time, cost, material, quality and environmental constraints.

Real estate development as an investment and why we should project manage building developments for success: Real estate professional practices anchors more on the success of building development success. The hope of property management and facility management is dependent on the success recorded in building construction projects. The right to rent, lease, sale and all other rights affiliated to them cannot exist or made promising or attractive if building development contracts are not project managed to succeed. Valuation of property, compensation promises will not be attractive without good investment in building development as there is no compensation for undeveloped land in Nigeria. More so, even production lines must operate in a building for there to be adequate plant and machinery valuation. The environment will not be aesthetically attractive in commanding reasonable value without massive investment on building infrastructure.

Real estate investors, either directly or indirectly, purchase rights to a stream of future cash flows that are expected to be generated by the real estate. The 
cash flow might come from rental income, from using the property as loan collateral, from cash savings through offsetting otherwise taxable income with taxdeductible losses from the real property interest, or from net profits upon resale of the property interest. The price an investor is prepared to pay for a defined property interest depends in part on the amount and the timing of these anticipated cash flows; how much will be received, and when? It depends also on the degree of confidence with which expectations are held and the investor's tolerance for bearing risk. The final variable is the attractiveness of alternative investment opportunities. Virtually any investment can be accommodated with a position in real estate. Speculators can deal in real estate futures( by buying and selling purchase options); developers can reduce risk exposure by using standby loan commitments or taking a position in interest rate futures; investors can buy fixed-income assets such as mortgage loans or net leased properties. Real estate can be even more attractive when approached, not as a simple investment, but rather as a business opportunity. In short, the possibilities are constrained primarily by limits on investors' ability to conceive of alternatives.

Real estate development and investment threats: Real estate investors are faced with various risks which may threaten their desire to invest in the sector. The major threats are:

$>$ The threat of building failure, abandonment and collapse of buildings during and after construction

$>$ Where to build, how to build and when to build

$>$ The opportunity cost in choosing to invest in real estate

$>$ Threat of losing financial asset and the risk associated with time value of money

$>$ Environmental challenges that influence or affect demand and supply of building accommodation within a geographical area; for example, flood erosion and gully erosion challenges, insecurity and other natural influences.

$>$ That rate of borrowing financial capital to invest and make profit with time.

$>$ The mode of measuring profit from real estate investment; a decreasing profit ( Arithmetic or Geometric Progression?) Increasing profit (AGP?).
$>$ Finally, government policies; a good example is the present Nigerian Land policy and various property taxes, levies, cumbersome processes in title registration and estate duties that does not only discourage investors but threaten investment interest in real estate development in Nigeria.

Our concern in this paper is how to handle the threat of building failure, abandonment and collapse of building infrastructure in which the solution lies with building construction project management.

\section{MANAGEMENT OF BUILDING DEVELOPMENT PROJECTS FOR SUCCESS}

Project management: The semantics of the definition of project management cannot be fully comprehended without a brief attempt to define the two major components "Project and Management".

Project: According to Ntamere, (1995) a Project is a discrete package of investment or endeavour, policy measures and institutional and other activities designed to achieve a specific objective or set of objectives within a designated period and involving the commitment of resources. To Osuagwu,(1997) a project simply means a series of related activities with a goal, a beginning, and an end. Hemuka, in his wisdom in an unpublished lecture, described a project as a form of investment or development which entails the injection of scarce resources, and other materials including land with the aim of realizing its latent potentials in form of yield, or for satisfying other social or economic benefits. A project is simply defined as any sequence of events or process which entails the putting together of different resources towards the attainment of a particular goal. A project can be distinguished by the following characteristics:

$>$ There must be a well articulated aim, goal or screened objective.

$>$ A life cycle with a starting and ending points.

$>$ It must have a network of timed and cost activities to produce a specified product.

$>$ The endeavour must be unique and nonrepetitive and one time program.

$>$ It may cut across many organizational lines.

$>$ Lastly, it may require the establishment of a special organization for its execution.

Building development is a good example of a project while project abound in all other sectors of 
human endeavour including Event Planning and Control.

Management: Management is simply defined as "planning, directing, controlling and co-ordinating of individual, group or organizational goal and objectives with the ultimate aim of achieving maximum benefit". In the view of Baridam, (2002), management literally means getting thing done through and with people, which has to do with the planning and directing of effort toward a common objective. The traditional functions of a manager reflect the activities involved in managing, planning, decision-making, organizing, staffing, leading, motivating and controlling. These functions constitute a circle of action in which each component leads to the next. Since building development project execution involves a consortium of various professionals; Architect, Engineers, Quantity Surveyors, Builders, Estate Surveyors, Urban and Regional Planners, etc it will be disastrous if there is non to co-ordinate their interest and roles as major stakeholders, together with other non-professionals and the client. The man to do the job is the project manager.

Project Management involves the proper welding together of the activities of all these professionals and non professionals by careful selection, coordination, programming, budgeting, monitoring their activities during the developmental process. The sequential steps in project management include:

$>$ Defining the objectives of the project.

$>$ Determining the task required to complete it.

$>$ Decide on important project milestone.

$>$ Determine the duration of projects component tasks.

$>$ Plan the most efficient organization of tasks.

$>$ Allocate resources to tasks.

$>$ Re-evaluate tasks relationships and schedules and finally carry out the project.

Project management is therefore, justified as a means of avoiding the ills inherent in building development, the entire construction industry and production sectors of the economy and for which reasons most projects fail, collapse or are abandoned. The project managers role arises from the need for a technical expert to take charge, control of events on the project implementation process, someone who understands the intricacies of co- coordinating, controlling, and directing the efforts and activities of the professional team and the physical problems of implementation process with the needs in the decision making process. The success of any project implementation process in the construction industry in the public and private sectors depend largely on the project manager's concept on staff appointments and control, strict monitoring of time, cost, material, quality and environmental constraints.

Project success, failure, abandonment and collapse of buildings: It is imperative to understand the above terms for us to really appreciate the functions of project management and the role of a project manager in actualizing project management goals.

Project success: According to Cleland et al (1975), a project is termed successful if it passes four success test criteria i.e. the time criterion completed on time; the cost or money criterion completed within budget; the effectiveness criterion completed in accordance with the original set performance and quality standards; and client's satisfaction criterion - accepted by the intended users or clients whether the client is internal or from outside the organization. The above success criteria call for successful project implementation by the utilization of proven management techniques of planning, organizing, directing and control. The issues on life cycle management, time management, conflict resolution and management, networking, contracts management, project choice and project quality are the key factors that contribute to project success. Effective project choice, for example, which results in a good project selection, greatly improves the probability of project success especially when the project is executed in accordance with project management implementation guidelines. The Critical Path Method (CPM) and Programme Evaluation and Review Techniques (PERT), for example, contribute a lot to project success as they foster a great discipline through definition of project scope, time scale/schedule and cost. Empirical evidence, however, suggests that the importance of networking is far overweighed by the contribution of other project tools, which include work breakdown structure, life cycle planning, systems engineering, configuration management and status reports.

Networking contributes to better cost and schedule performance but not necessarily to better technical performance and better client acceptance. Perceived success is more adequately defined as meeting the project's technical specification or mission while at 
the same time attaining a high level of satisfaction on the part of the organization, clients, users and the project team (Beker et. el, 1988) . The end product must perform satisfactorily in service. This means that parties associated with and affected by a project should be satisfied in all its ramifications by the end product. Effective project success therefore requires a judicious trade-off amongst the four tests or success factors of timeliness, completion within the budget, satisfaction in technical performance, and client or customer acceptance.

Project failure: Project failure is illustrated by a failure to achieve the four success criteria and is manifested by the lack of application of proven project management techniques. It does not mean that the project may not have been physically completed but the question is when is the completion? Is there any time or cost overrun? Is the quality specified standard achieved? Can it stand the test of time? Can its potential be maximally realized? Is the client and end-user satisfied? If the client is proposing another project, can he insist on working with the same team? If the answers to the above questions are in the affirmative, the project is termed successful but if otherwise it means a failure.

Project abandonment : Project abandonment is the unplanned suspension of the work progress especially at the execution stage such as refusal or failure to complete a contract after practical completion time period. Abandonment and failed projects which are more predominant in the public sector litter every gamut of the nations environment including government quarters, university campuses etc. The phenomenon cuts across many economic sectors including the construction, manufacturing/industrial and service sectors. There have been cases when non-functional, unusable or unserviceable projects have been commissioned as "completed". A monumental economic loss is incurred in terms of heavy cost overruns, periodic waste of resources and projects that metamorphose into bottomless pits gulping scarce resources with no concrete completion time in sight. Several Federal Housing projects initiated at different periods, Health facilities especially primary health projects and divisional hospitals across the length and breadth of this country, these and more are eloquent testimonies of project abandonment and /or failure. This phenomenon would have been avoided or drastically reduced if judicious applications of project management principles were accepted and applied. Various reasons were given for the abandonment of the most projects in Nigeria. They include: escalation of project cost due to inflation, difficulty in payment to contractors due to government bureaucracy, contractors performing below expectation, frequent changes in government, inability of sub contractors such as those in charge of electrification to adhere to schedule, increase in the scope of work, change in pre-contract consultants such as architects, poor or ineffective project finance arrangement, change in the original design, indiscriminate award of contracts without reference to funds availability, projects completed but technically unsound and unable to function, materials scarcity, poor planning or shoddy work by architects, consultants, etc specification of costly imported materials, increase in contract sums, poor project definition in terms of project requirements for materials, equipment, personnel, finance and other resources, correlates of effective project management, insufficient working capital, the ailing economy and general inflation. The above examples and the reasons adduced for project failure and abandonment can be traced to a number of factors including poor or no project appraisal, top management lapses, defective contract agreements and awards, and gross failure to apply project management techniques. Contracts for projects are awarded without adequate project planning which includes the costing and scheduling as well as the method for successful implementation. A mismatch often exists between project design and objectives on the one hand, and the implementation capacity of the agency or organization or ministry on the other. There is often a defective control system, and in some cases, the system of monitoring and evaluation may be completely lacking. Where projects are awarded on political considerations little or no attention is given to the recommendations of project appraisals, assuming that such specific studies are undertaken.

Budgetary constraints occur frequently given the short tenure of governments, reordering of priorities or diversion of fund as time progresses. Project abandonment or failure is the inevitable outcome of the above mentioned scenario. Should the project be included in the new set of priorities, tremendous cost and schedule over-runs are highly probable because of likely changes in resource requirements, escalation in input prices and changes in the organization or implementing unit. This is aggravated by the fact that the contractor may have to deal with different 'owners' or officials at different times during different stages of the project life cycle. Often, projects are completed not within budget, time, and 
technical specifications and within customer or client satisfaction. The projects are "completed" but cannot function. All the above causes of project abandonment will be minimized or eliminated completely if a trained project manager is in charge from the conception stage.

Building collapse: The collapse of building infrastructure, though prominent in developing economies is a worldwide issue. Building developments collapse at the construction stages and in some cases after commissioning. Examples abound in recent times in Abuja and Lagos. The major problem is the unquantifiable resources wasted when building construction development collapses. If the answer to this endemic problem is proper project management, it becomes imperative to institutionalize its activities in Nigeria.

How to manage building development projects for success using project life cycle concept: The project manger make use of the life cycle concept as a valuable tool for better understanding of the stages of a project and likely resources required for its successful implementation. The life cycle is used to pictorially explain the rise and demise of organizational phases in building of structures, production line and sales life cycle of a product. It is also one of the instruments that help managers conceptualize the work and budgetary requirements of the project.

The basic life cycle concept holds for all projects and systems. Life cycle management is heeded because the life cycle reflects every different management requirements at its various stages. In the beginning, for example, in terms of manpower- human resources-research personnel predominate, subsequently, their role diminishes at the planning stage. The execution which is more of concrete work features more of engineers and finally marketing and sales personnel become more important. In a product development, for example, performance would be assessed by the degree to which the product meets the specification or goal set for it. The detailed explanation of the activities of the four phases is reflected in table 1.0 below.

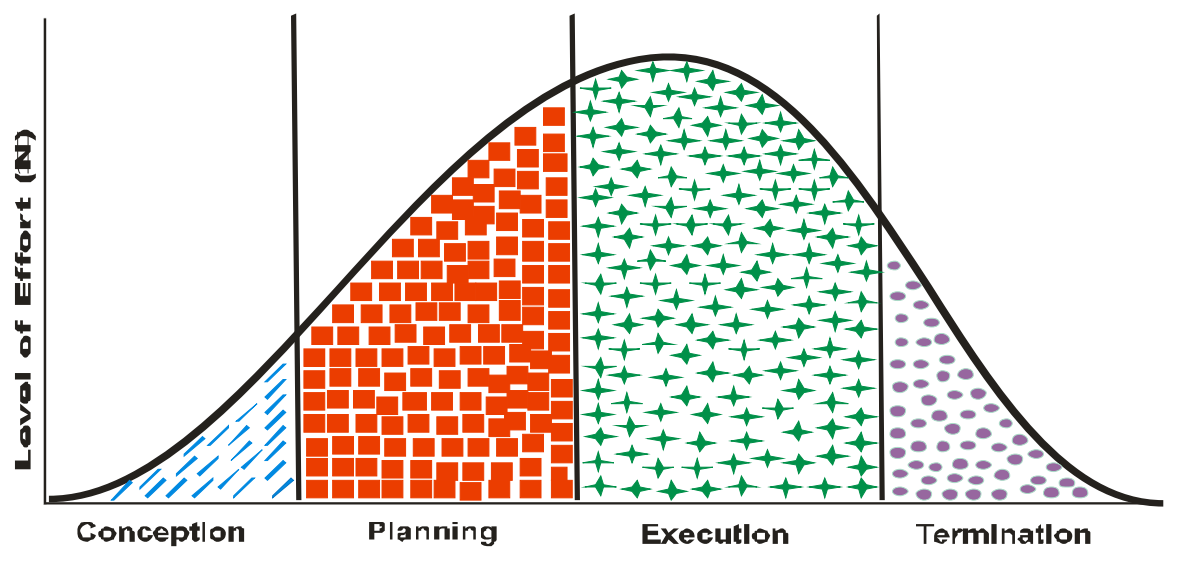

Table 1.0 Life Cycle Activities

\begin{tabular}{|c|c|c|c|}
\hline $\begin{array}{l}\text { Conception Phase } \\
\text { * Identify need }\end{array}$ & $\begin{array}{l}\text { Planning Phase } \\
\text { *Implement schedule }\end{array}$ & $\begin{array}{l}\text { Execution Phase } \\
\text { * procure materials }\end{array}$ & $\begin{array}{l}\text { Termination } \\
\star \quad \text { Train } \\
\text { personnel }\end{array}$ \\
\hline${ }^{\star}$ Establish feasibility & $\begin{array}{l}\text { * Conduct studies and } \\
\text { analyses }\end{array}$ & * Build and test tooling & * Transfer materials \\
\hline *Identify alternatives & * Design systems & $\begin{array}{l}\text { *Develop } \\
\text { requirements }\end{array}$ & *Transfer responsibility \\
\hline${ }^{\star}$ Prepare proposal & *Build and test prototypes & * Produce system & *Release resources \\
\hline $\begin{array}{l}\text { *Develop basic budge and } \\
\text { schedule }\end{array}$ & *Analyze results & * verify performance & $\begin{array}{lll} & \text { *reassign project } & \text { team } \\
\text { members } & & \end{array}$ \\
\hline${ }^{\star}$ Identify project team & $\begin{array}{l}\text { * Obtain approval for } \\
\text { construction }\end{array}$ & * Modify as required & \\
\hline
\end{tabular}

Source: Project Management Handbook 
Am. J. Soc. Mgmt. Sci., 2011, 2(1): 56-75

Table 2.0 Taxonomy of Strategic Versus Tactical Issues

\begin{tabular}{|c|c|c|c|}
\hline & & STRATEGY & TACTICS \\
\hline 1. & $\begin{array}{l}\text { Level of conduct- level within the } \\
\text { organization at which project } \\
\text { implementation activities and issues are } \\
\text { performed or addressed }\end{array}$ & Top management & $\begin{array}{l}\text { Mid-to lower levels of } \\
\text { management }\end{array}$ \\
\hline 2. & 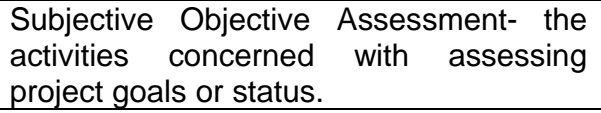 & $\begin{array}{l}\text { Great subjectivity used at } \\
\text { strategic level }\end{array}$ & $\begin{array}{l}\text { Less use of subjective } \\
\text { values }\end{array}$ \\
\hline 3. & $\begin{array}{l}\text { Nature of problem- The type of problems, } \\
\text { which arise and must be dealt with during } \\
\text { the project implementation process. }\end{array}$ & Unstructured one at a time & $\begin{array}{l}\text { More structured and } \\
\text { repetitive }\end{array}$ \\
\hline 4. & $\begin{array}{l}\text { Information Needs- the determination of } \\
\text { the types and quality of information that is } \\
\text { required for the project. }\end{array}$ & $\begin{array}{l}\text { Large amount } \quad \text { of } \\
\text { information needed much } \\
\text { that is external }\end{array}$ & $\begin{array}{lr}\text { Need for } & \text { internally } \\
\text { generated, } \\
\text { information. }\end{array}$ \\
\hline 5. & $\begin{array}{l}\text { Time horizons- The scope or time frame } \\
\text { of management's vision in implementing } \\
\text { and evaluating the project. }\end{array}$ & $\begin{array}{l}\text { Long-term, but it varies by } \\
\text { the problem. }\end{array}$ & $\begin{array}{l}\text { Short-term and more } \\
\text { constant. }\end{array}$ \\
\hline 6. & $\begin{array}{l}\text { Completeness- The degree to which the } \\
\text { scope of the entire organization is } \\
\text { considered. }\end{array}$ & $\begin{array}{l}\text { Covers the entire scope of } \\
\text { the organization. }\end{array}$ & $\begin{array}{l}\text { Concerned only with the sub } \\
\text { organizational unit involved. }\end{array}$ \\
\hline 7. & $\begin{array}{l}\text { Reference-Involves the source, or frame } \\
\text { of reference, of the activity to be } \\
\text { considered. }\end{array}$ & $\begin{array}{l}\text { The source of all planning } \\
\text { in the organization is } \\
\text { original. }\end{array}$ & $\begin{array}{l}\text { Done in pursuit of strategic } \\
\text { plans. }\end{array}$ \\
\hline 8. & $\begin{array}{l}\text { Detail-Concerned with how broad or } \\
\text { specific problems are laid out and how } \\
\text { generally they need to be addressed. }\end{array}$ & Broad and general. & Narrow and problem specific \\
\hline 9. & $\begin{array}{l}\text { Ease of Evaluating-The ease of } \\
\text { determining the efficiency and } \\
\text { effectiveness of various activities } \\
\text { involved in the implementation. }\end{array}$ & $\begin{array}{l}\text { Difficulty, } \\
\text { generality }\end{array}$ & $\begin{array}{l}\text { Easier, } \\
\text { specificity. }\end{array}$ \\
\hline 10. & $\begin{array}{l}\text { Point of View-The assessment of the } \\
\text { focus of viewpoint of the various actor's } \\
\text { involved in the project implementation. }\end{array}$ & & \\
\hline
\end{tabular}

Source: Project Management Handbook

To enhance project success the following strategies or guidelines are recommended; As much as possible adopt the project management approach, project objectives should be clearly spelt out, clear objectives create the conditions for the attainment of good results, project requirements should be clearly defined in terms of resources, time scale, technical approach and the required technology.

The operators should develop an ability to manage change - which is a major objective of the project management approach. Plan soundly, good information flow is necessary, there should be a clear definition of responsibilities, project selection, location and implementation should not be politicized, there must be a clear definition of project scope and knowledge of factors that can affect the project scope and pay critical attention to project financing.

The time is ripe for increased application of the project management approach in Nigeria in both the private and public sectors. The application will result in effective project selection and execution. The use of task forces to handle specific problems is a pointer to the need for the adoption of project management strategy. Agencies such as NDDC, ITF are built around the project management idea. Projectization (application of project management concept) of certain projects will reduce a lot of bureaucracy and redundancy in many organizations. Moreover, the project management elements of planning, scheduling and control will introduce the much needed discipline for the satisfactory realization of project goal.

In general, life cycle events vary with phases. Project size is quite different across the phases. The planning and the execution phase have by far the largest project teams. The level of bureaucracy parallels this pattern, with the greatest level corresponding to the greater size; the organizational climate is such that in the early and later phases it is 
more participative while it is different in the middle phases. Conflict entirely decreases consistently across the phases. Job satisfaction seems to be highest for the smallest, more organic organizations and lower for those organizations mostly mechanistic in nature (Adams 1990). In Process, involving initial strategic actions and supporting tactical activities, there are further implications for project performance based on a consideration of strategic and tactical issues. Table 2.0 shows breakthrough of strategy and tactics by high and low scores depending upon the level to which these issues were addressed in the project implementation. A high "score" on strategy would imply that the strategy is well developed and effective, as in the similar case with tactics. This value could be assessed either in a subjective or intuitive manner.

\section{Project success implementation factors:} According to Clayland, et al (1975) the process of building project implementation involving the successful development and introduction of projects in the organization, presents an ongoing challenge for managers. The building implementation process is complex, usually requiring simultaneous attention to a wide variety of human, budgetary and technical variables. A project manager is often faced with difficult job characterized by role overload, frenetic activity, fragmentation and superficiality. A project manager in spite of all these has the responsibility for successful project outcomes without sufficient power, budget or people to handle all of the elements essential for project success. In addition, projects are often initiated in the context of a turbulent, unpredictable, and dynamic environment. A project manager would be well served by more information about those specific factors critical to project success. The project manager requires the necessary tools for him to focus attention on important areas and send different priorities across different project elements. It can be demonstrated that a set of factors under the project managers control can have a significant impact on project implementation success. The project manager should be better able to efficiently and effectively deal with many demands created by his job, channeling his energy more efficiently in attempting to successfully implement the project under development. His controlling ability is demonstrated in the ten key factor model of the project implementation profile below.

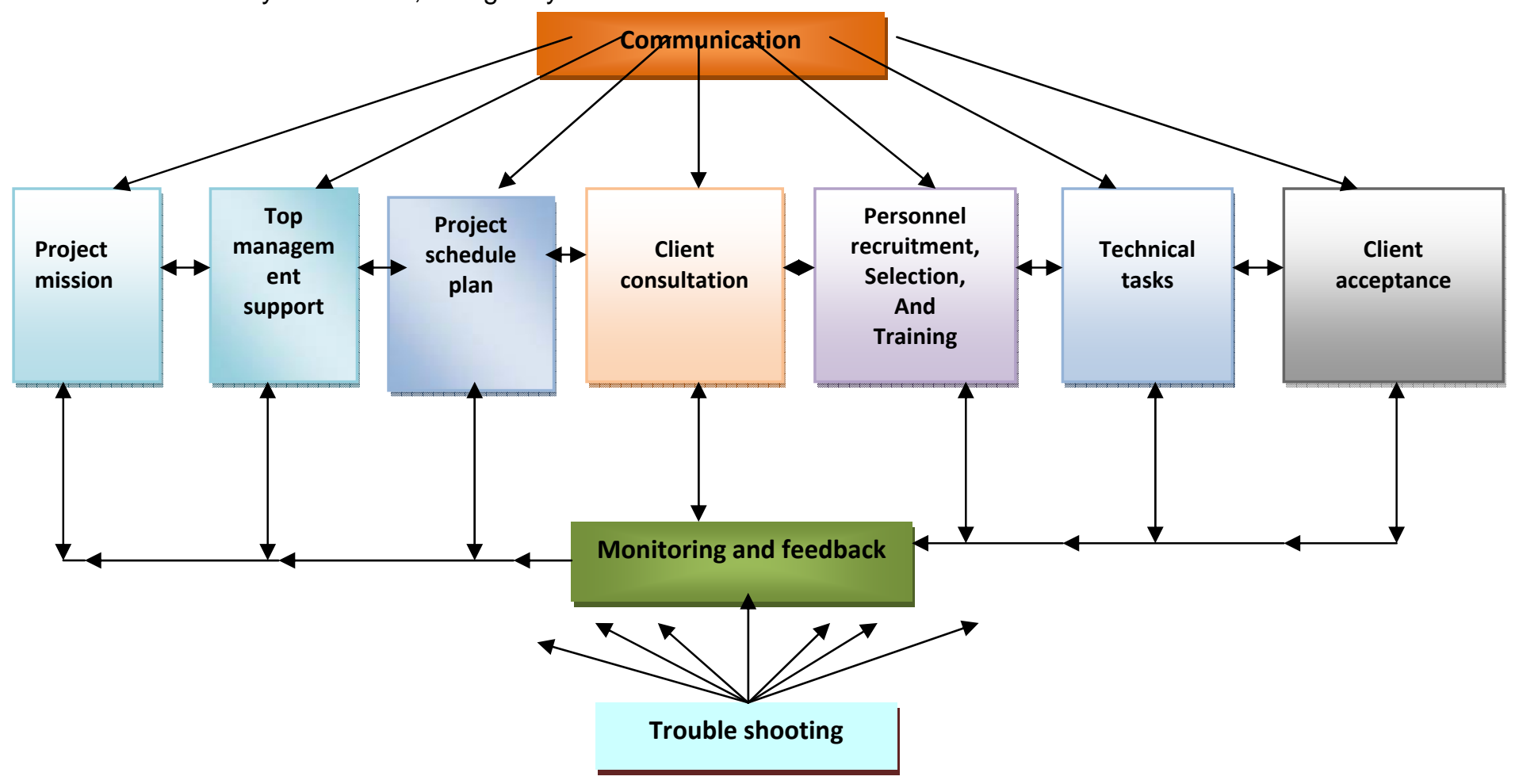

Fig 2 Ten key factors of project implementation profile

Source: Project Management Hand Book 
Slevin et al (1986) studied many projects in their bid to evaluate factors that constraint success in project management; they articulated many factors but narrowed them down to what they christened ten key factors of project implementation profile as reflected pictorially above.

Communication: The need for adequate communication channel is extremely important in creating an atmosphere for successful implementation of a building project. Communication could best be describe as the life wire of any project implementation success. There should be prompt communication to the building or project mission, good information flow with the top management, the building or project scheduled plan, always consulting the client, adequate communication to personnel issues like recruitment, motivation and training etc, good understanding of the technical task and staff, sequential monitoring of all work and processes given feedback to the stakeholders, always active in communication with trouble shooting indicators, communicating with the client at all times sensitizing him with every issue that will enable him to accept the product after execution.

Project mission: Project mission is the same as clearly defined goals and objectives. Project mission has been found to refer to the condition where the goals of the building project are clear and understood not only by the project team involved but by the other departments in the organization.

Top management support: Slevin, et al (1979) noted that management support of projects especially building construction has long been considered of great importance in distinguishing between their ultimate success or failure. Beck(1979), sees project management as not only dependent on top management for authority, direction, and support, but as ultimately the conduct of implementing top managements plan as goal for the entire project organization. The degree of ultimate acceptance or resistance to the project shows the degree of management support of the project.

Project scheduled plan: According to Pinto et al (1989) this refers to the importance of developing a detailed plan of the required stages of the implementation process. This is the origin of life cycle concept in building construction projects.

Client consultation: The need for client consultation has been found to be increasingly important in attempting to successfully implement a building project. Manly, (1987) found out that the degree to which clients are personally involved in the implementation process will cause great variation in their support for the project.

Personnel issues: Personnel issues include recruitment, selection and staff training for the building project. An important, but often overlooked aspect of the building implementation process concerns the nature of the personnel involved. In many situations, personnel for the building team are chosen by the client especially in the public sector building construction with less than full regard for the skills necessary to actively contribute to the implementation success.

Technical tasks: This is very important in that the people who understand the project must manage the implementation. Stevin (1977) writing on implementation risk analysis identifies two of the eight risk factors as being caused by technical incompatibility.

Monitoring and feedback: Monitoring and feedback refer to building project control system or processes by which at each stage of the implementation, key personnel receive feedback on how the project is comparing or conforming to initial projections in time management, cost, quality and materials.

Troble shooting: Problem always exist in almost every project especially building construction, they could be seen as conflicts which lead to the success or failure based on how it is being managed by the stakeholders, in fact, conflict according to Nwachukwu, (2010). Is seen as an indispensable force that propel the wheel of success in any building project implementation process.

Client acceptance: This is the final stage in building project implementation process at which time the ultimate efficiency of the project is determined. For there to be a successful handover of the developmental product, there is need to carry the client along by prompt communication and feedback throughout the stages of the building project life cycle.

Project management tools : Project management tools are mainly planning and implementation tools at various stages of the project life cycle which is expected to foster success in the implementation process. At the conception stage, an effective and efficient appraisal is a very strategic and significant tool used in establishing the feasibility and viability of a project proposal. It helps us to determine investment alternatives, how much to invest, how to 
invest, where to invest, Cost benefit analyses of economic and social proposals, spillover advantages and disadvantages of project proposals, the rate at which a prudent investor could make profit with time, determine time value of present financial expenditure against future expected income and the environmental impact assessment of project proposal etc. Appraisals is an instrument used in processing social and economic dreams to a tangible and realizable aims and objective which must be unique in nature. Some of the tools as we know include: The Net Present Value (NPV), Internal Rate of Return (IRR), The Net Terminal Value, The Annual Charge, The Annual Sinking Fund and Cost Benefit Analysis.

Network planning: Network planning is one of the most significant project management techniques used in planning, scheduling, and controlling a project. Planning technique is vital at all the stages of a project life cycle. It is a continuous process because of the prevailing need to keep track of progress changes, delays or changes in technical conditions. Delays and changes in project implementation are controlled by the application of critical path methods. They enable management to cope with the complexities, messes of data and tight deadlines characteristic of many industries and their environment that is highly competitive.

It is important to know at this stage that Planning and Scheduling are not synonymous. Planning is the establishment of objectives, definition of the content of the project and the determination of the relationships between the jobs or activities. On the other hand, Scheduling is the development of a time table that puts time estimates next to the plan and indicates when activities are to be accomplished. That is, time estimates, timing calculations and job scheduling are involved.

Pert and cpm networks: Programs Evaluation And Review Technique (PERT) and the Critical Path Method (CPM), The Bar and Gantt charts used in scheduling, tracking, resource smoothing and performing time and cost-trade-offs at the execution and termination stages are the best tools for project planning and control. The PERT and CPM techniques help to determine cost-effectiveness as a way to expedite a project knowing that certain projects can be rushed for a price. This method has been successfully and advantageously used in developed economies for planning large scale and complex projects and we strongly believe that it can be an antidote to transform the building development sector if project management is given a policy thrust status in Nigeria. PERT was first used in the 1950s to manage the Polaris Missile Program. Since then the technique has been successfully used by private and public industries and sectors such as; construction of complex building structures, shopping, office and subways, major maintenance efforts, pilot production runs and the introduction of new products. Whenever faced with complex situations, a manager should use these techniques, their cost is less than the benefits.

The two types of PERT are the Deterministic and the Stochastic.

Deterministic PERT assumes that all tasks that make up a project are sufficiently routine in the sense that the time needed to complete each tasks is known with reasonable certainty.

Stochastic PERT on the other hand is often used to plan either research or one-of-a-kind development project because of the valuable insights gained by the very act of identifying intermediate milestones and establishing logical process among them.

\section{Producing the project plan}

By Paddy Lewis (2009)

In producing a project plan, you need to establish these:

$>$ Project planning process

$>$ Work breakdown structure

$>$ The Project Plan

$>$ Purpose

Contents

$>$ Production and Use of the Plan

$>$ Time Management

\section{WHY PLANNING}

Facilitates effective project management

$>$ Best assessment of how project will be implemented

$>$ Baseline against which to measure performance

$>$ Gains commitment

$>$ 'The means is more important than the end'

\section{Work breakdown structure (WBS)}

Work Breakdown Structure (WBS) has the following characteristics:

$>$ It is representative of work as an activity, and this work has a tangible result

$>$ It is arranged in a hierarchical structure

$>$ It has an objective or tangible result, which is referred to as a deliverable 


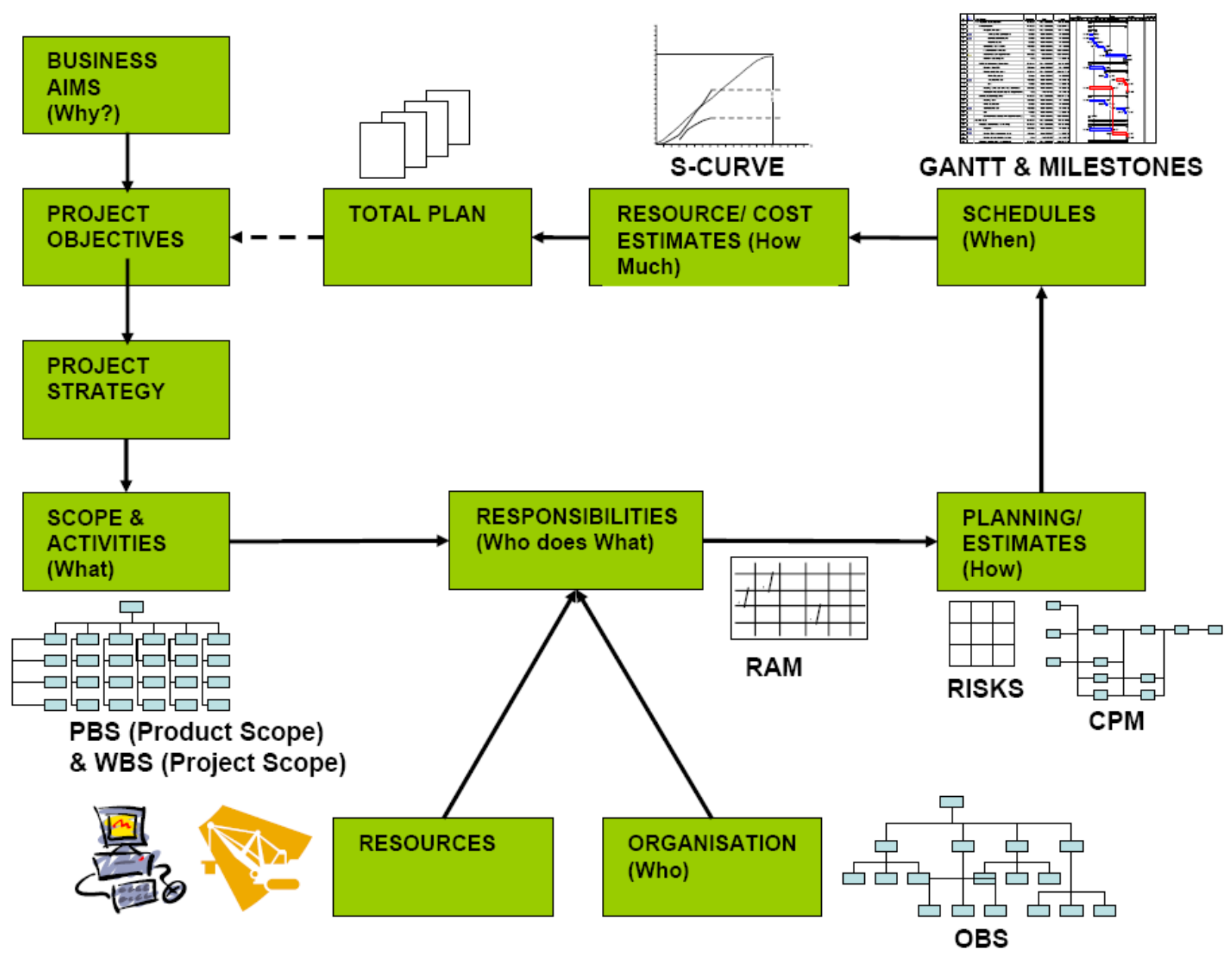

Fig 3 Project Planning Chat

Source; Authors Network Plan in Nwachukwu C.C (2010)

\section{Preparation guideline for project planning}

\section{First step is PBS (Project/Product Basic Steps)}

$>$ Identify the final products of the project what must be delivered to achieve project success known as PBS

$>$ Always a good idea to review the high-level project scope documents for guidance

\section{Second step is}

$>$ Identify the major deliverables necessary to meet the final products

$>$ Often these major deliverables are predecessor Deliverables Theater needed to build what has been committed to, but that in themselves do not satisfy a business need (i.e., a design specification).

\section{Third step}

> Incorporate additional levels of work detail appropriate for management insight and integrated management

$>$ Best done in conjunction with development of Fourth step project strategy

$>$ Review and refine the WBS until project stake-holders agree that project planning can be successfully completed

\section{EARLY DEFINITION OF PROBLEM}

Early definition of problem is very important for successful completion of project with time schedule and budget. The possibility of effecting changing in 
the operation depends on the time at which problem has been identified.

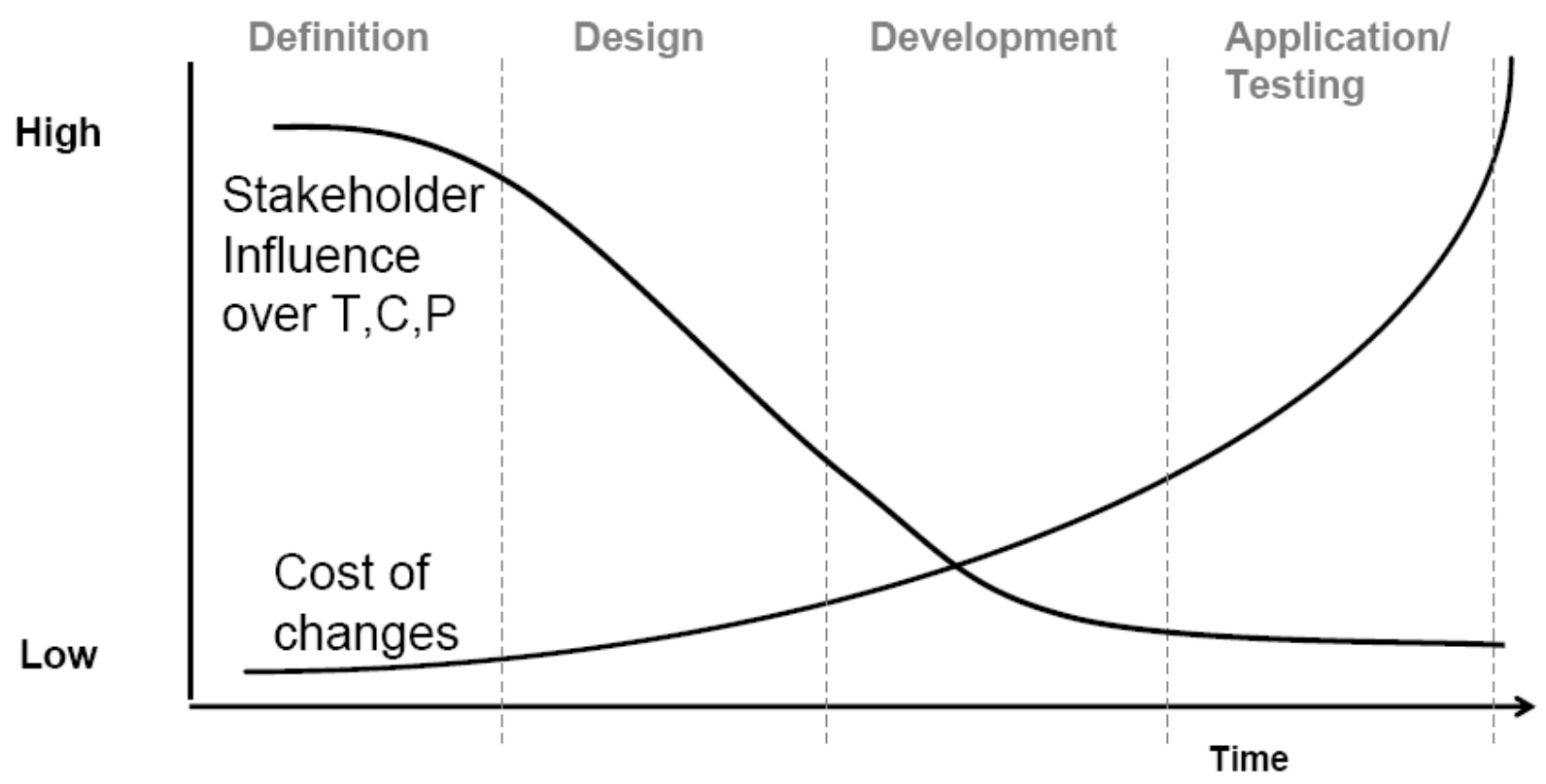

Fig 4 Problem definition diagram

Source; Authors Network Plan in Nwachukwu C.C (2010)

\section{ORGANIZATION AND RESPONSIBILITY}

Organization Breakdown Structure (OBS): Organization breakdown structure covers all those involved in the project and helps in defining organizational roles and responsibilities and structure of the project team.

Activity Definition - identifying the specific schedule activities that need to be performed to produce the various project deliverables

Activity Sequencing - identifying and documenting dependencies among schedule activities

Activity Resource Estimating - estimating the type and quantities of resources required to perform each schedule activity.

Activity Duration Estimating - estimating the number of work periods that will be needed to complete individual schedule activities

Schedule Development - analyzing activity sequences, durations, resource requirements, and schedule constraints to create the project schedule

Decompose the project (WBS, WBS Dictionary)
Rolling Wave Planning - Work to be done soon is planned in detail at a low level of the WBS; Work in the future is planned at a high level of the WBS

Planning Component - When insufficient definition of the project scope is available to decompose a branch of the WBS down to the work package level, team can develop a high-level project schedule for that component

Project schedule: Generally, the site supervisor will prepare scheduling reports to be evaluated and recommended by the client. The scheduling technique used will be the Precedence Diagram presented in the form of Microsoft Project or Primavera computer software.

This method of scheduling is becoming more widely used in most of the construction projects. Thus, with this new technique, the process of construction in future can be identified and understood.

\section{PROJECT SCHEDULE NETWORK DIAGRAMS}

These diagrams with activity date information, usually show both the project network logic and the project's critical path schedule activities. They are appropriate for detailed team analysis but not for high/senior level presentation. 
Am. J. Soc. Mgmt. Sci., 2011, 2(1): 56-75

\begin{tabular}{|c|c|c|c|c|c|c|c|}
\hline 0otes: & d Soneduls wh Los del Aestonstids & & & & & Dene & \\
\hline \multirow{2}{*}{$\begin{array}{l}\text { Activit } \\
\text { ioverinar }\end{array}$} & \multirow{2}{*}{ Mitivity bescriction } & \multirow{2}{*}{$\begin{array}{l}\text { Eset } \\
\text { dar } \\
\text { wess }\end{array}$} & \multicolumn{5}{|c|}{ Project Soneduk frma Fume } \\
\hline & & & Pervod 1 & Pesot 2 & posed 3 & Prrice 4 & Pen 60 \\
\hline 1.1.1.8 & 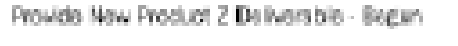 & $\theta$ & & & 1 & & \\
\hline 1.1.t & Wak Poskage 1 - Dewloe Sensonam! 1 & 87 & & & & & \\
\hline 1.1.1.0 & Design Componant 1 & 20 & & Ifes & 1 & & \\
\hline \$.1.1.8 & Euld Conponemt 1 & 33 & & & & & \\
\hline 1.1.1.T & Tont Componem 1 & 14 & & & & & \\
\hline L.A.t.ne & Connovent 1 Canwintad & 0 & & & & & \\
\hline 1.1 .2 & Work Pacaage 2 - Dwweg Conconam 2 & 53 & & & & & \\
\hline 1.1 .20 & Desibi Conponent 2 & 14 & & & 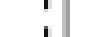 & & \\
\hline 1.1 .28 & tusd conponent 2 & $2 s$ & & & & & \\
\hline 1.1 .2 .7 & Test Carnoinem 2 & 11 & & & & & \\
\hline 1.J.2nel & Comconem 2-Cerrouses & 9 & & & & & \\
\hline 1.1.3 & Work Pacauge 3 - Integente Cornpanents. & 53 & : & & 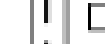 & & \\
\hline$\$ .1 .3 .0$ & Imesase Corrosnarta 132 & 24 & & & & & \\
\hline $118 \mathrm{~T}$ & Tost imsaratori hrone ore 7 & 32 & & & , & -2 & \\
\hline $1.1 .3 P$ & Defieer Product $z$ & T & & & & & \\
\hline 1.1.MF & 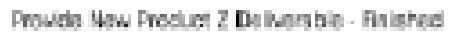 & 0 & & & ' & & \\
\hline
\end{tabular}

Fig 5 Schedule Network diagram

Source; Authors Network Plan in Nwachukwu C.C (2010)

Project schedule using bar chart:These charts, with bars representing activities, show activity start and end dates, as well as expected durations. Bar charts are relatively easy to read, and are frequently used in management presentations.

\section{Summary Schedule}

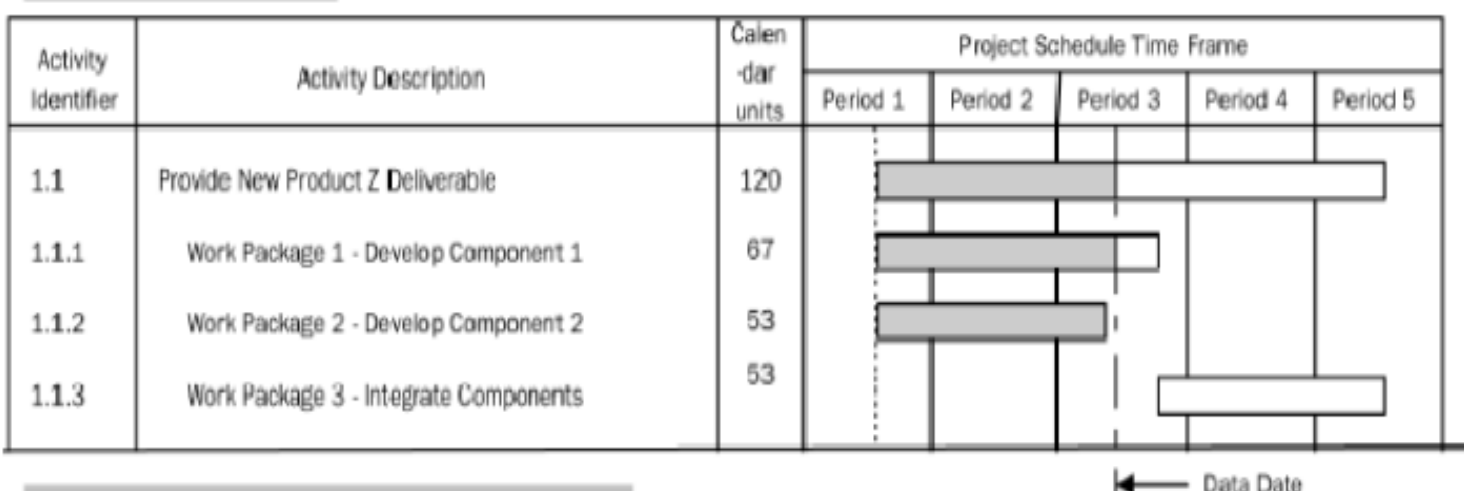

Fig 6 Bar Chart

Source; Authors Network Plan in Nwachukwu C.C (2010) 
Project schedule formats - milestone charts: Similar to bar charts, but only identify the scheduled start or completion of major deliverables and key external interfaces. Excellent for presentation at a summary level and can serve a motivation to the project team.

\section{Milestone Slip Chart}

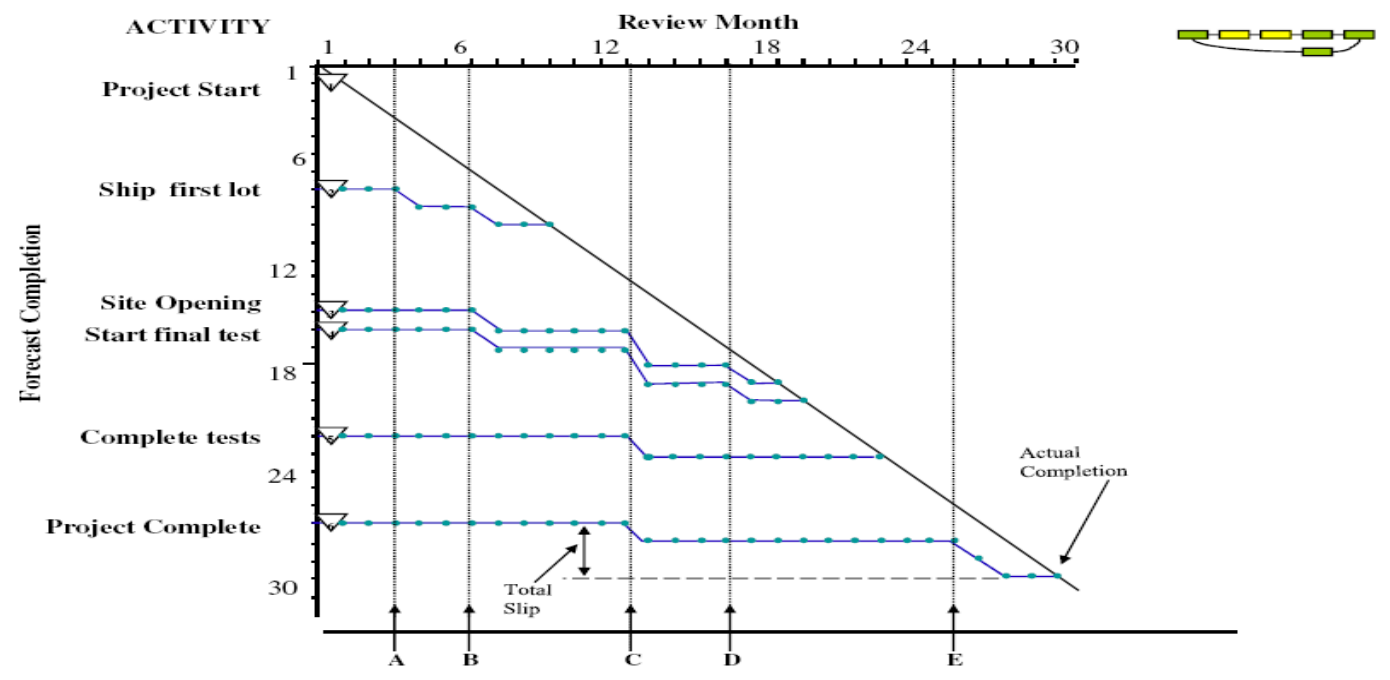

Fig 7 Mile stone chart

Source; Authors Network Plan in Nwachukwu C.C (2010)

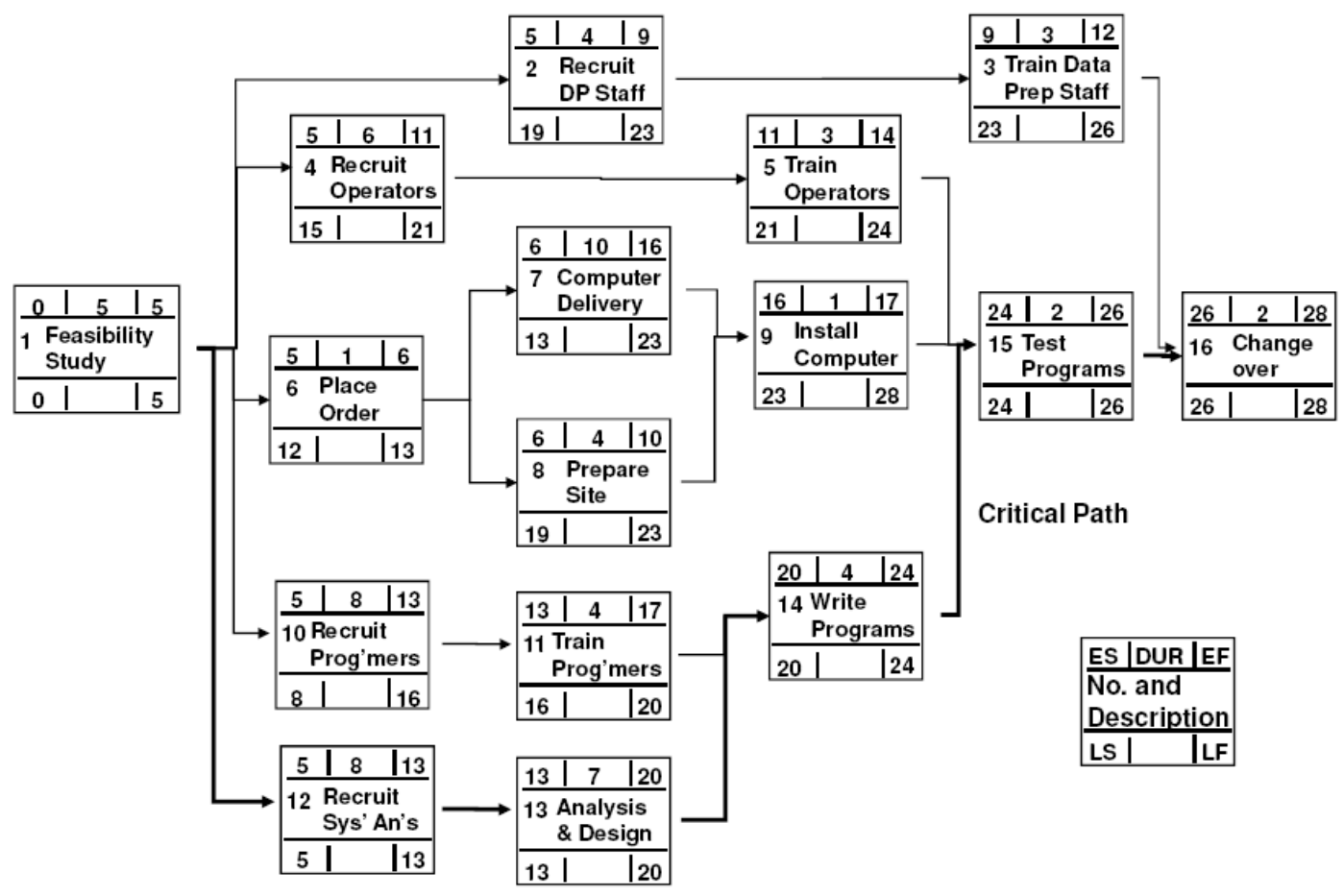

Fig 8 Precedence Network - Example

Source; Authors Network Plan in Nwachukwu C.C (2010) 
Critical path and float: Critical Path: longest sequence of activities, shortest duration for project

Total Float: time an activity can be delayed without affecting project end date

Free Float: time an activity can be delayed without affecting any other activity

The justification and role of a project manager in ensuring project implementation success: The construction of a building requires a competent building team, example; the designer (Architect), Engineers, Builder, Quantity Surveyor, Estate Surveyor etc. Any of the above if specially trained as a project manager is qualified to project manage a building construction process. What justified him is not only his professional background that gives impetus to his technical ability but a training in project management. His role arises from the need for a technical expert to take charge and control of events on a project site. A professional who both understands the intricacies of co-coordinating, controlling, planning, and directing the efforts and activities of the professional team, who also have good understanding of the basic contents of all the technical application required of each profession who's professional is a member of the development team, who is familiar with the physical problem of construction and the decision making process.

Project management is justified according to Nwachukwu et al (2010) as a means of avoiding the ills inherent in the building construction industry and all other sectors of the economy and for which reasons most projects fail, are abandoned, and collapse. The main justification in using a project manager in managing building construction process as an opportunity cost to all other professionals is because capital is scarce and the risks of development are high in an inflation prone economy like ours. To this end therefore, care must be taking to committing the scarce resources and other human resources into a project with uncertain end. Also the intensity of capital and the risks inherent in development, justifies project management as an apparatus to check the colossal waste of funds in little- understood investments when such funds have better alternative uses.

The role of a project manager include:
$>$ Co-ordinating and supervising all aspects of the work program and ensuring that quality is maintained

$>$ That works or various activities are completed on time and at the right budget

$>$ Liaison with all the parties involved in the project including the developer and the development team

$>$ Directing and controlling the contractors and sub contractors to curb the excesses, wastage, delay and unnecessary foot dragging

$>\mathrm{He}$ advises on design and cost, and with his experience in value management or engineering analyses he is able to attain set goals without sacrificing standards and quality

$>\mathrm{He}$ advises on taxation and legal matters taking percussion in ensuring that the project meets the budget

$>$ Site assembling and procurement of professionally acceptable feasibility studies

$>$ Determines type of funding arrangement, negotiates for funds and procure funds for the project execution in line with feasibility studies

> Monitors cash flow during period of construction and makes adjustment where necessary

$>$ Create a cordial working environment among consultants, contractors and every other worker on site.

It is evidence that the role of a project manager cannot be exhausted, but his role can be seen primarily as that of reducing the client's (developers) problems and increase his control over the project in terms of the accuracy of the clients brief, the various options open to him, budgeting and programming of works he acts as a shock-absorber to the client, and as a catalyst to the development team. He is the engine that gives the development process is locomotive force, and of course the fulcrum that gives leverage to success of the entire project. He may not be a magician, but he possesses scientific tools and techniques that make things work like magic. 
Responsibility of some stakeholders in building project success : In order for the construction plan to meet all these requirements, though, it must have the willing cooperation and buy-in of the owner, construction manager, sub-contractors and designers. In short, everyone needs to have some degree of ownership in the plan. For that reason, it's important that the owner or construction manager to have the input of every major player in the project during the design stages of the construction Project.

As early as the bidding stage, it pays to be open to suggestions and communication. Being open to input from bidding subcontractors allows the plan to be refined based on the experience and capabilities of those who have tackled similar work in the past. If those lines of communication are open from the very start, every subcontractor who makes a successful bid has a realistic stake in the project because they feel they helped define the tasks and timetable. Without it, updating the schedule regularly becomes a time-wasting chore in their minds. When a contractor and his crew have an investment in the plan, they feel they are helping to manage it rather than being a slave to it.

\section{Project manager:}

$>$ Shall ensure that information concerning the work is obtained.

$>$ Plans, directs and monitors the activities of the project team.

$>$ Shall ensure required resources - personnel, equipment and materials are present on-site and are in the right quantity and condition.

\section{QUALITY MANAGER}

$>$ Assigns quality personnel to follow and inspect the job, as well as ensuring that the procedure has been distributed through DCC.

\section{Human resourse site manager}

$>$ Shall ensure that a fit for purpose joint human action is produced for the activity.

$>$ Shall ensure that there is proper control of all activities throughout the operation in such a way that safety of personnel and equipment are not compromised.

$>$ Shall ensure that there are appropriate signals to warn and / or direct other road users.
$>$ Shall ensure that open excavations are properly barricaded.

$>$ Shall ensure the use of appropriate and certified equipment for various activities and the operation of such equipment by certified personnel

$>$ Shall implement the JHA.

\section{Construction technical manager}

$>$ Manages all activities related in the procedure concerning the construction aspects of the project.

$>$ He shall be the focal point for all construction matters. He is responsible to ensure that the quality of the work is maintained

$>$ Contributes towards the quality plan for the project, in particular, the quality performance requirements of construction.

$>$ Shall ensure adherence to the method statement and other approved standards, relevant to the activity.

$>$ Ensures adequate monitoring process in place to enable effective site supervision in line with execution and construction standards.

Discipline supervisor (forman) : He shall be responsible for performing all necessary activities to ensure that the quality of the work has the minimum requested level of quality related in the quality control plan Inspection and Test Matrix associated to this procedure on site.

$>$ Contributes towards the quality plan for the project, in particular, the quality performance requirements of construction.

$>$ He shall be in possession of the "Approved for Construction" drawings (alignments sheets) and survey reports in order to be followed and assure that during the stringing and bending activities the pipes are located in the correct location.

\section{Quality inspector/supervisor}

$>$ He shall be responsible for monitoring on site the execution of the job, collecting relevant Quality Records and makes sure if the records are properly filled out and archived.

$>\mathrm{He}$ shall be responsible for performing all necessary inspection and verifies that the 
activity is being carried out as per requirements and standards, as established in this document and in the Quality control plan Inspection and Test Matrix filing out the correspondent quality report.

\section{Human resourse site supervisor}

$>$ He shall ensure all personnel are available on site prior to the commencement of the operation

$>\mathrm{He}$ shall liaise with the medical team to ensure adequate provision of medical evacuation of injured personnel and facility from the site for timely medical care.

$>$ He shall ensure proper and adequate waste management on site.

$>$ Provision of adequate personnel flotation device (PFD) should be made available

$>$ He shall ensure that rules are observed on site.

\section{Human resourse site officer}

$>\mathrm{He}$ shall ensure that pre job meetings including tool box meeting, Job Hazard Analysis (JHA) are conducted prior to the commencement of the operation.

$>$ He shall ensure that rules are observed at site.

$>$ He shall properly coordinate flag bearers to ensure safe traffic at the site of operation.

$>$ He shall ensure the availability of appropriate work permit on site.

$>$ The provision of all safety devices will be his responsibility.

Clint's/owners: This is the individual, the firm, or the organization that funds the construction project and will own the completed facilities. The owner, perhaps assisted by consultants, specifies the scope of the construction project.

In some instances, the owner may specify the detailed layout of the facility, the type of materials to be used, and so forth. The owner, perhaps assisted by some of the parties described below, and depending on the technical expertise of his or her own staff, may inspect the project work as it is being performed and on its completion. The golden rule in the construction process is: "He who has the gold makes the rules." Because the owner controls the purse strings, he or she dictates the kind of contract that will be used and selects the other parties to the project.

The designers: They may be employees of the owner, but are more often recommended by the project manager. In addition to designing a building facility that meets the expressed needs of the owner and that complies with applicable building codes, the Architect may be retained by the owner to act as his or her representative in inspecting the project work, to review and approve materials that the contractor proposes to use in the work, to review and recommend contractor requests for progress payments, and to perform other functions on behalf of the owner especially where there is no trained project manager.

The contractor and sub-contractors: These are individuals or firms that undertake to perform required construction work in return for a contract price. Contractors may be categorized as prime contractors and subcontractors. Prime contractors have a contractual relationship with the owner, whereas subcontractors have a contractual relationship with the prime contractor or with another subcontractor. General contractors are prime contractors who contract to perform specified work, possibly excluding some specialty items such as electrical and mechanical work that the owners desire to contract directly with the specialty contractors.

Resources for project planning and execution: When everyone is together, it is more possible to identify needs for additional manpower, added equipment, and potential time loss and gain. If a delay has caused the loss of time, the entire team can work on recovering the lost time. If there is a gain, the team can come up with the best way to use the gain.

There are many method employed in project planning. Many project planners were used to table form which comprises a date list, starting or completed information, which are provided by the management. Regardless of the methods employed, the decisions made will require the collection of data on materials, machineries, equipments, manpower, finance and time.

Construction materials: The measurement of quantities by the quantity surveyors and specifications can be summarized to determine the particular quantity and types of materials to be used to perform a task. The availability and delivery period for these materials should be obtained and from suppliers or according to experience.

Machineries and equipments: The machineries and equipment which are required to complete a construction project will definitely depend on the suitable types and the method adopted for safe keeping. After the selection on the particular 
machineries or equipments is made, the availability and delivery time must be determined.

Heavy machineries such as cranes, excavator, side boom, pay loader, cement mixers, steel bar cutter and steel bar bending machines for structural works are required during the execution of the work and efforts should be made to reduce if not eliminating or preventing idling which will induce a high cost overrun.

Labours and manpower: Labourers and other nonprofessional manpower personel are critical and important assets in construction project management success. Without labourers, a building project cannot stand the test of time and must fail or suffer abandonment. Thus, labourers should be taken into account when scheduling work to ensure that their participation is at the maximum standard.

Finance: The allocation of finance must be scrutinized to reimburse for the cost of the supply of construction materials, personnel and machineries. Any financial difficulties must be resolved to ensure that the construction project can be carried out smoothly.

Time: The most crucial element which must be carefully monitored is time. The owners will normally check for starting dates, completed dates and other relevant yet important dates in contract submissions by the contractors. Besides, there are also time limits which must be obeyed by construction organizations during planning stage.

The time require for the construction materials to be delivered to site should follow a specified schedule. This is to fulfill worker's demand and reduce wastage. A proper understanding of the project requirements will enable a more effective and efficient materials handling at site.

Proper consideration of weather: Once a detailed schedule has been developed and the expected start date for the work is known, the project team should review the activities in relation to the time of year in which they are scheduled. In cold weather climates, activities which fall in the winter months may need to be shifted, or it may be necessary to plan for temporary enclosure and heating. Similarly, the schedule may need to allow more time for certain activities or show them being done on a limited basis because of weather considerations. Similar issues may arise in extremely warm areas or areas which have a rainy season. If a revised project start date or other delays shift the work by several months, the schedule should be updated and the activities that have shifted into bad or difficult weather periods should be looked at closely and adjusted as needed to reflect the effect of weather.

CONCLUSION: Project management indexes has been described as the secret weapon of developed nations in attracting investors to investing in building development. Its methodologies, approach and principles have helped such world powers as United States of America guide their development processes; and in the United Kingdom where the office of government commerce devised the Prince II Methodologies to grow their economy. Therefore, in driving our developmental targets, it has become imperative to institutionalize this world acclaimed solutions vehicle into our economy for the achievement of our nation's development goals. One of the major problems of project management in Nigeria is corruption. The question is. how do we intend to tackle that? If project management is a policy thrust, it will create rules for everybody to play by.

As earlier stated, all the issues that relate to construction sector are very relevant and indispensable in the economy.

Construction sector is seen as the pivot on which every other activity in the economy rotates on. The significant importance of this sector is evidenced in the fact that every business or services of diverse kinds must have a shelter and a location in the environment. Therefore, any effort towards reducing or eliminating the noticeable and silent constraints that directly or indirectly affect project management success in this sector is a right step in the right direction. The stake holders in any complex building construction project are numerous and varied with parochial objectives different from the main objectives of realising the cost, time, quality and materials targets of the proposed construction projects. Proper project management policy we believe, is the only solution in making sure that building construction and developments do not fail, collapse, or are abandoned at alarming rate in Nigeria as such threatens the foundation of economic growth and slim down the chances of realising vision 20:2020project of the federal government.

\section{RECOMMENDATIONS}

Having seen the imperative for project management, we strongly recommend that it should be a national policy to be enshrined in the Constitution of the 
Federal Republic of Nigeria as we advocate for constitution amendment.

Every organization in all the major and minor sectors of the nation's economy is encouraged to establish the department of project management. A project manager should be appointed early enough in the project life cycle to handle the management from inception to completion.

Every building development must have a resident project manager and not one project manager handling the management of more than one project at a time for an organization, for this will create loopholes in realizing the development goal. There is strong need to use the modern project planning and control techniques in achieving the required quality and material targets of a development aim and objective.

For public building development projects , government should set up a Project Management Office (PMO) under the office of the President/Vice President or Governor/Deputy Governor to provide substantive professional project management support for national and state project planning, execution, monitoring/control and close out.

If proper project management is institutionalized, it would bring about authenticity of data or information, timely release of funds, effective management of project risks and realization of project benefits in both public and private sector of the economy.

We recommend as critical the need for the intervention of academic researchers and major stakeholders from building construction industry for a scientific study on other factors constraining project management success in public and private sectors of the building development industry.

We also recommend that a comparative study be undertaken to determine the level of building development project management performance between foreign and indigenous development firms. To this end, we are very optimistic that an empirical study in these areas may provide a level ground for all the stakeholders, clients, designers, contractors, users, financiers and sponsors to rub minds on how to drastically reduce if not eliminating these disastrous elements as constraining factors to building development project management success in Nigeria.

Finally, Professor Nwachukwu, a production engineer, once said in a private chart that Estate Management discipline is closer to Project
Management than any other discipline. To this end therefore we suggest that Project Management profession should be institutionalized as an integral option, branch and or part of Estate management profession especially in postgraduate studies. As other professionals encroach in Estate Management functions like agency and management of building infrastructure, we can launch out to project management practices which have virgin opportunities like Events Planning, Events Management and Events Control etc. see the appendix for a pm curriculum in some foreign universities

\section{REFERENCES}

Abacon, C. I (2008) "The Eight Keys to Project Management hailure", hal/l workstar.net/library/hpm.htm

Accorf, D.C (2008) " Project Failure Warning Signs", http://www.bluejeansplece.com/project management failure warning signs.html

Avots, I. (2001) "Why does project Management Fail?" California Management Review II: 77-82

Baker, B.N., Murphy, D.C. \& Fisher, D. (2000) "Factors Affecting Project Success". In Cleland and King (1986) Project Management Handbook. Vol.2 45-51 U.S.A: 920-34.

Barnes, M. (2000)"Construction Project Management" International Journal of Project Management, Vol. 6 No.2.

Bhavesh, .M. P (2006) Project Management (Strategy Financial Planning,

Evaluation and Control) PTV Ltd, New Delhi

Clifford, F. Gray and Erik W. Larson (2003), Project Management (The Managerial Process), McGraw Hill. Irwin, New York.

Churchill, G.F. (1988) "The Role and Relevance of Quality Assurance to Control" In Nuclear Power Station Project Management, Proceeding of the British Nuclear Energy Society, London. 20-20 July 35-46.

Curry, B.G, and Avary, C.N. (2005), Construction Project Performance, McGraw-Hill Irwin, New York

Diakwa, M.M (1990) "Bureaucracy: Key Obstacle of Project Success" American Associates of Cost Engineers Transactions: p.4.1-5.

Eric, C.E., (2003) Facility Design and Management Hand book, McGraw-Hill, New York.

Frank, H and Ronald M (2001) Modern Construction Management, Blackwell Science Inc., USA. 
Frascer, D.C. (2006) "Risk Minimization in Giant Projects" Proceedings of International Conference on Successful Accomplishment of Clients projects, London. 17-18 May.

Fryer, B. (2003) The Practice of Construction Management, $2^{\text {nd }}$ edition, BSP professional Books, oxford, London.

Galsim, B. (1998) "An Approach to Project Management", Cost Engineering, Vol.26 No. 3:23-5.

Giwa, S.L. (1988) "Differences between Initial and Final Contract Sums of Construction Projects in Nigeria: Causes and Solutions" The Nigerian Institute of Quantity Surveyors Seminar.

Harold, K. Re(2004) Project Management, ( A Systems Approach to Planning, Scheduling and Controlling) S.K Jain Publishers, New Delhi, India.

Hamburger, D. (1999) "The Project Manager: Risk Taker and Contingency Planner. Part 1: The Project Manager as a risk Taker" Project Management Journal, Vol. XXI No. 2

Hayfield, F. (2006) "Basic Factors for a Successful Project" Proceedings $6^{\text {th }}$ International Congress Garmisch. Partenkirchen Federal republic of Germany.

Igwe, B.N.U. (1990) "Stages of Project Planning and Management Cycle" Unpublished Paper.

International Labour Officer (2007) Guidelines for The Development of Small Scale Construction enterprise, Ilo, Geneva.

Jaafari, A. (1986) "Strategic Issues in Formulation and Management of Macro Projects in Australia". International Journal of_project Management, Vol. 1 No. 2.

Knoepel H. (2000) "Cost and Quality Control in projects Cycle". International Journal of Project Management, Vol.7 No. 4.

Kumar, D. (1999) "Developing Strategies and Philosophies Early for Successful project Implementation" International Journal of project Management. Vol.7 No. 3:164-171.

Lewis, B.O.B (2008), “ The 70\% Failure", info world. http://archive.infoworrld.com/articces/op/xml/01/10/29/o1 1029/opsrvival. xml

Mansfield, et al (2003) "Reforming Project Management" http:///weblog.halmacomber.com//

Metzger D.Z. (2006) "Systems Approach to Strategic Project Management". International Journal of Project Management. Vol.7 No.3

Moavenzadeh, F. \&. Rossom, J.A (2000) "The Construction Industries in DevelopingCountries". Technology Adaptation Program RPT. MIT. Use (Spring).

Muspratt, M.A. (2000) "Conditions Affecting Projects in Less Developed Countries". International Journal of project Management. Vol.5, no.1:45-53.
Nwachukwu C.C, Echeme, I.I and Okoli, M.N (2010) "Project Management Factor Indexes; A Constaint to Project Implementation Success in the Construction Sector of a Developing Economy" European Journal of Scientific Research" July edition ISSN1450-216X Vol.43 No.3, pp392-405 United Kingdom.

Nwachukwu C.C, Emoh F.I, and Egolum C.C (2010) "Equating Cost Constraint Factors to Construction Project Management Success in Nigeria (an analytical approach)",UNIZIK Journal of Environmental Sciences, vol. 1, No 1 pp18.

5. Nwachukwu, C. C and Nzotta, S. M (2010) Quality Factor Indexes; A Measure To Project Success Constraints In A Developing Economy, Interdisciplinary journal of Contemporary Research in Business (IJCRB), June editionVol.2,No.2 United Kingdom.

Nwachukwu, CC, (2009) "Optimization of Design Constraining Factors to Project Management Success of Public and Private Sector Construction in Nigeria (An Analytical Approach)", Interdisciplinary journal of Contemporary Research in Business (IJCRB), Vol.1,No.5 United Kingdom.

Nwachukwu, CC (2008) The Analysis of Factors that Constraint Project Management Success of Public and Private Sector Construction in Nigeria, Ph.D Thesis, FUTO

Nwachukwu, C.C. (2003) "An Empirical Analysis of Sources of Conflict in Project Life Cycle Management JIBER, volume 7 No. 1 (23-37).

Nworuh, G.E Cr(2004) Basic Research Methodology for Researchers Trainees and Trainers in Management Sciences, Ambix Printers Nigeria, Owerri.

Okereke, P.A. (2003) Construction Materials, Crown Publishers Limited, Owerri.

Sasillo, S.I. (2006) Management of Contracts in The Construction Industry with Case study On Management of the Construction Industry in_Tanzania. MSc. Thesis, University of Strathclyde, U.K.

Silver E.A (1988) "Material Management in Large-Scale construction Projects: Concerns and issues". Engineering, Costs and production Economics, 15, Eleeviser science publishers B.V. Amsterdam: 223-9.

Yaseen A.M \& El-Marashly, A.F. (1989) "Project Quality Control Management: A Conceptual Framework". International Journal of Project Management. Vol.7, No. 2: 84-90.

Youker, R. (1989) "Managing the project Cycle For Time, Cost and Quality: lessons from World Bank Experience". International Journal of Project M 